UDC 811.111'27

\title{
COMMUNICATIVE AND PRAGMATIC LEVEL OF VERBAL MANIPULATION
}

\author{
Lina Sorokina, \\ $\mathrm{PhD}$ in Philology, \\ Senior Lecturer of the Department of Foreign Languages for the Humanities, \\ Lesya Ukrainka Eastern European National University, \\ Lutsk, Ukraine \\ linanivska@gmail.com
}

Received May, 7, 2018; Accepted June, 1, 2018

\begin{abstract}
This article focuses on the study of communicative, pragmatic and gender aspects of verbal manipulation, throwing light on its manifestation in Modern English dialogical discourse. Dialogical manipulative situations have been revealed and classified on the basis of their discursive communicative and pragmatic characteristics. The analysis of differences in men's and women's manipulative utterances has been performed.

The article analyzes the discursive nature of the verbal manipulation, establishes the models of its implementation in English dialogical discourse taking into account the gender aspect. The basic structural model of the manipulative situation in the dialogical discourse consists of such components: an addresser, an addressee, a message, an addressee's and addresser's worlds, communicators' visionary worlds, a social situation, each of which forms its own level.

The basic means of the "addresser-addressee" level are communicative roles, which are divided into standard and initiative. The latter is subdivided into active and passive roles. Women's manipulative speech is characterized by initiative roles of care, benevolence and interest. For men, such a communicative behavior is possible only in connection with the role of an expert or the standard communicative role (a son, a brother, a husband). Women also use the role of an expert, but in combination with the standard roles of their sister, girlfriend, and mother. The analysis of communicative roles allowed differentiating between cooperative and conflictive types of the manipulator.
\end{abstract}

Key words: dialogical manipulative situation, dialogical discourse, verbal manipulation, gender, communicative role, standard role, initiative role.

\section{Introduction}

Modern communicative linguistics is characterized by the growing interest of scholars in the language potential as a means of influence, and in particular, its ability to act as an instrument for manipulating both the individual and society as a whole. In addition, a human factor is in the focus of modern scientific work, there, i.e., all individual peculiarities of the linguistic personality, including its gender, which plays an important role in the social, cultural and cognitive orientation of a man. Despite a large number of studies on manipulative influence, there has not yet been a thorough research of the manipulative potential of communicative roles, in particular in the dialogical discourse. Thus, the purpose of the article is to investigate the manipulative features of standard and initiative communicative roles, taking into account the gender factor. 


\section{Approaches to the structure of communicative model}

Discourse is a complex communicative phenomenon, which, in addition to linguistic, also embraces extralinguistic factors (knowledge of the world, skills, settings, goals of the addressee), which are necessary for an adequate perception of discourse. The latter is understood only when the situation under discussion is comprehensible (Velychko, 2008; Karpchuk, 2006). The discourse is "based on the situation" (Shmidt, 1978: 94-95) provokes it and displays it. But it does not occur directly, only due to the author's perception of the text and through the reflection in the mind of the author. The communicative situation ensures the coherence of discourse, its adequacy, correct interpretation, ascertaining its implications and presuppositions.

Thus, in R. Jacobson's model (Jacobson, 1975: 194), the standard communicative situation includes six components: an addresser, an addressee, a context, a contact, a code. The contact refers to the interaction between communicators and the peculiarities of their actions. A message is certain information communicated from one person to another by means of a code (a language in the broad sense). The context in this model is related to the content of the transmitted information. Each function in the model expresses a direct impact on the corresponding component. The scholar points out the context as a separate constituent part, although for our structural model of dialogical manipulative situation, the context is considered as verbal and should be regarded as the one belonging to the same level as the statement.

Sociolinguistic interpretation of R. Jacobson's communicative-informative model is the model by D. Hymes (Hymes, 1975: 58-64). Seven out of sixteen components of his model are the most relevant for our study, namely: an addresser (a person who creates and sends the message), an addressee (a person to whom the message is addressed), a topic (the information transmitted to message), code (a system of signs and rules for their combination for the transmission of a message on a particular channel), a form (special grammatical and lexical message selection), a channel (an environment not only physical, but also social, historical, cultural, meaning, in which the transmission takes place and perception of information), a place of action (social or physical context). In D. Hymes' model, the topic and place of the action replace and clarify the context factor in R. Jacobson's model. The factors of the addresser and the addressee are considered in terms of the social roles of participants in the communicative act. The location factor, in turn, depends on the types of social situations. The positive feature of this model is that it is designed not to be a perfect communicative act, but oriented primarily to carry out the research, where the main subject is the addresser's speech activity aimed at the addressee.

In the formula of the speech act by N.I. Formanovskaya "who - who - what when - why -what for" the sender, the recipient, the message (the topic) - "what", the context (time) - "when", and also the separate motivational characteristics of the sender - "why", "what for" (Formanovskaya, 2002: 25). From our point of view, I.P. Susov's opinion (Susov, 1986) sounds far more appropriate in this sense. The scholar believes that in each communicative act, the speaker creates communicative and pragmatic space around himself, the compulsory components of which are: the 
speaker, his addressee, the statement, the subject of the statement, the time, place and circumstances of the interaction act.

Despite the fact that these communication models have their own differences and characteristics, they all emphasize the fact that the final link of the process of formation and conveying the information is the addressee that decodes the message according to his background knowledge. The message that has specific effect (rational or emotional) is created particularly for him. However, mentioned above models do not take into account the social roles of the addresser and the addressee, their personal interactions within the discourse, therefore we consider it to be efficient to suggest our own model of the dialogical manipulative situation (hereinafter the DMS).

\section{The structure of the dialogical manipulative situation}

Based on the communicative model by K. Serazhym (Serazhym, 2002), we consider that for our DMS modeling the dialogical discourse the following components are essential: the addresser, the addressee, the message, the addresser's world, the addressee's world, the addresser's visionary world, the addressee's visionary world, the social situation (time and physical space of communication).

The addresser (manipulator) is a communicator that generates ideas or collects and conveys information in the course he needs. The manipulator can be an individual (as in our research) or a group of people (in the political, mass-media or advertising discourse). One of the conditions for the effectiveness of manipulative influence is the knowledge about the recipient. If the manipulator has erroneous views about the recipient of the message, then his communicative efforts will prove to be ineffective. In order to achieve the maximum of manipulative effect, the addresser, formulating a specific statement, simultaneously solves a number of extra-language problems: 1) the hypothetical recipient construction in the aspect of his social and psychological portrait; 2) modeling relations with the recipient in the aspect of social norms and ethics, psychological state; 3 ) prediction of the recipient's reactions.

According to researchers (Bykova, 1999; Dmytruk, 2006; Mikhaleva, 2003; Chaly, 2008), the addressee remains a passive participant in a dialogical manipulative situation, who is imposed, prompted the information, or provoked to certain actions without his consent. In this case, the addresser is an active participant in the communication process, and the recipient remains passive: the latter is offered a completed and verbally designed product of reflection, and he himself does not make any special mental efforts. However, we do not agree with this statement. Any manipulation, as well as communication, is an interaction. The interaction between communicators in this sense will be effective on condition the recipient under the influence of the received signals rebuilds his worldview, thoughts, goals, and starts to operate according to the new program. Only in this case the manipulation is considered to be successful. S.G. Kara-Murza (Kara-Murza, 2009: 47) defines manipulation as the temptation but not violence. Thus, the manipulator will use his / her entire linguistic range of strategies and tactics so that the temptation will become an essential reality. 
A message is information encoded with symbols, which is communicated to the addressee. Symbols can be both verbal and non-verbal (facial expressions, gestures, graphic images). Within our work, it is not possible to provide study ofnon-verbal means of manipulation due to the requirements for the volume of the article. However, such a task will be considered as perspective for further scientific investigation in this field. An important characteristic of a manipulative message is its strategic direction, which allows the addresser to influence the addressee.

The addresser's and the addressee's worlds form a conceptual system, i.e., a non-discrete, constructed and modified dynamic data system (representations, considerations, knowledge) that is operated by the individual; the volume of his active thesaurus; a set of the individual's consciousness models, which determine his perception of himself and his place in the world.

By constructing a worldview model of a partner, the participants of communication process take venture to expect, predict, anticipate the partner's response (Serazhym, 2002: 49). That is how communicators' visionary worlds are built up, with the only difference: the recipient does not see manipulative intention in advance (provided that he himself does not have manipulative goals), and the addresser, in turn, in addition to predicting the response of the addressee, uses all his knowledge about the partner of communication for their own purposes and, as a rule, not in favor of the addressee.

In our study the social situation is regarded as a natural fragment of a social life, which is determined by the local and temporal aspects of the statement.

The communicators' move to manipulative interaction begins with the actions of one of them, the one who is initiating, at least at the initial stage of manipulation can be considered as its initiator. If in the future the initiative is left by one of the parties, then it is regarded as active (manipulator's part), and the other is regarded as the passive part (the one who is manipulated).

Structural features of the DMS with all the essential components, at the same time, do not allow predicting the development of the manipulation. Therefore, the article focuses on one of its components i.e. the communicators' roles in the development of a dialogical manipulative situation.

\section{Communicators' roles in the development of a dialogical manipulative situation}

The binary anthropocentric opposition "addresser-addressee" acts as the basic opposition to the category of addressability of dialogical discourse. There is no balance between the members of the opposition because the degree of dependence of the addressee from the speaker and, conversely, the speaker from the addressee varies in a certain way. The recipient appears as the object of perception and the subject of response, the expression of which depends on the speaker's utterance, although the addressee is not a passive object of the interaction, since the message of the latter largely affects the choice of verbal means that will be used by the speaker.

When it comes to manipulation, most scholars (see, for example, (Bykova, 1999; Dementiev, 2006; Chaly, 2008) are of the opinion that the addresser always 
dominates, while the recipient remains a passive participant in the dialogical manipulative situation, but we support the validity of the theoretical positions of Yu. S. Stepanov (Stepanov, 1995: 31) on the unity of the addresser and the addressee and the regulatory nature of their relationship. This unity is not only the result of the intentions of the manipulator or the addressee, but also the property of discourse, which manifests itself in the fact that the addresser and the addressee act as relative quantities, the actualization of which is regulated by a certain general function provided by the discourse. According to N. P. Karpchuk (Karpchuk, 2006: 33-34) discourse provokes certain expectations that determine the so-called preunderstanding, on the basis of which the addresser makes the choice of the discourse of his own. In the process of perceiving the chosen discourse, an addressee who possesses sufficient cognitive space, individual experience, readiness for interpretation, and formed expectations projects them into the semantics of discourse and its individual fragments, fills in the text gaps (presuppositions, implications) and thus, ascribes specific meanings to the discourse and its components, at the same time reducing polysemantic possibilities of discourse to one possible interpretation.

The statement about the unity of the addresser and the addressee seems to us the most liable, because the addresser always creates a discourse, guided by a hypothetical addressee (especially, if it is a case of verbal manipulation). The latter, in turn, plunges into the world of the author's perception of reality, and, on the other hand, uses his own life experience. This means that the addressee is an important factor in creating a manipulative situation. Even if the recipient completely abandons the individual self and unconditionally supports all addresser's points of view, it should be recognized that a similar act of self-denial is also a manifestation of the addressee's activity.

A characteristic feature of dialogical discourse as a method of interpersonal interaction is the constant change in the communicative roles of the addresser and the addressee, which reflects the relationship plan dynamics of the two main anthropocomponents of the communication act. But even more important when considering the manipulator's activity seems to be the characteristic which he acquires in the process of communication. A communicative role is interpreted according to I. A. Sternin (Sternin, 2001: 79) as an image that a person creates in communication to achieve a certain goal. The scholar classifies the communicative roles into standard (a person's communicative behavior; the one that is acceptable in the society for the corresponding social role) and initiative (the image that a person deliberately creates in communication to achieve a certain goal). Regarding the standard role, the author interprets it as a form of behavior adopted by society, formally established or unofficially recognized place of the individual in the hierarchy of the social group. I. A. Sternin believes that the same roles can be both social and communicative: the difference is that a role is social if a person is a leader, a professor, a sick person, a father, etc. in the real life, and it is considered to be communicative when he / she pretends to be them (Sternin, 2001). In this case, the speaker acts as an expert of performing communicative roles, and this often helps him to be successful in his manipulative influence. 


\section{Types of communicative roles and their function in the dialogical manipulative situation}

In our study, we initially divided communicative roles into active and passive ones. Several basic communicative roles are identified among them:

- active: experienced / reputable, caring / friendly, interested;

- passive: inexperienced, weak / tired, a simpleton.

Consider an example in which the manipulator performs an active leading role of the benevolent woman.

(1) (a) 'I know you wanted to say goodbye to them, but I really think they're best left.(b) They'll only be upset if they see you now.' 'I suppose so,' said Celia, 'but I wouldn't wake them, Nanny, I just want to look at them. I'm not going to see them for more than three weeks.' (c)'Well - be all right if you went in to the twins, I suppose,' said Nanny, 'but maybe not Barty.' 'Why not?' (d)'She was crying earlier. For her mum. You know how she does sometimes. I gave her a cuddle, read her a story, and she went off fine. But if she wokewell. Best not risk disturbing he' (Vincenzi, NA, 2004: 171).

The communicative situation is as follows: Lady Celia is in a hurry to go on a long-awaited trip and she wants to say goodbye to the children, one of which (Barty) is an adopted child. In the fragment (1) the manipulator is a nurse who plays the leading active role of a caring, benevolent woman. It is this communicative role that helps her to carry out verbal manipulation. Each of her utterances (a, b, c, d) corresponds to the created image. In fact, the nurse did not tell Celia about an important detail - Barthy's. Moreover, she didn't send for the doctor knowing that the girl is seriously ill. Nanny's argumentation demonstrates her destructive intentions. She tries to prove that for her lady the trip is more important than a girl. In general, this DMS is classified as destructive, since the manipulator's intention involves moral damage to the addressee (Celia) and the physical harm to the object of the referential situation (Barthy).

One more example is the dialogue where both communicators are manipulators (2) who perform opposite communicative roles. Van der Merwe is a real swindler and a criminal who at one time defrauded and hired murderers to get rid of Jamie. Mr. Travis (also known as Jamie) had a miraculous escape and so decided to take revenge. Van der Merwe gradually plays several leading active roles: first, a caring business man (a, b), then the role of an experienced expert is added (d). Jamie, respectively, plays the communicative role of an inexperienced but secure heir, who needs an authoritative help (c).

(2) (a)'I might be able to be of some service. One has to be careful. There are many immoral people around.' (...) (b) 'If it isn't too personal, Mr. Travis, may I ask how you acquired your fortune?' 'I inherited it from my father,' Jamie said easily. 'Ah, but I'm sure you've had a lot of business experience.' (c)'Very little, I'm afraid. I need a lot of guidance.' Van der Merwe brightened. (d) 'It's fate that we met, Mr Travis. I have some very profitable connections. Very profitable, indeed. I can almost guarantee that I can double your money for you in just a few months.' (Sheldon, MG, 2005: 125).

It is important to state the fact that our study of gender-based manipulative behavior confirms the research of experts in the field of gender about the authority of 
male speech as a type of verbal activity, which creates the position of an expert for the speaker (Tannen, 1990; Holmes \& Meyerhoff, 2003). Women's manipulative speech is marked by initiative roles of care / benevolence, as well as interest. For men, such communicative behavior is possible only in addition to the role of an expert or with standard communicative roles (e.g. a son, a husband). Women can also perform the role of an expert, but in combination with the standard role of a sister, a girlfriend and / or a mother.

Standard communicative roles also contribute to successful verbal manipulation. It is easier to manipulate, provided that your standard social role is a mother, a brother, a girlfriend, etc. As a rule, both roles are closely intertwined in the image created by the manipulator, in particular, a caring husband, an experienced mother or an affectionate friend, for example:

(3) (a) 'I hate like hell to bother you, Kat.(b) I really do. But I got into a small jam.' His voice sounded strained. (c)'Mike ... are you all right?' (d) 'Oh, yeah. It's nothing serious. It's just that I owe somebody who needs his money back right away, and I was wondering ...' 'I'll see what I can do,' Kat said wearily. 'Thanks. (e) I can always count on you, can't I, sis? I love you. 'I love you, too, Mike.' (Sheldon, NLF, 1995: 124).

The above fragment (3) illustrates the informal DMS, in which the standard role of the brother allows the manipulator to solve their problems at the expense of his sister one more time. In fact Kate loves and is greatly worried about Mike - the only dear person for the sake of who she is ready to do anything. He realizes it well, besides, he is accustomed to the role of an inexperienced little brother who is not able to cope with any problem on his own. The very beginning of the dialogue (a) I hate like hell to bother you, Kat contains a presumption that something did happen. The following utterance is a general information about minor troubles (b) that causes the recipient's natural sense of care (c) and allows the manipulative brother to hint what exactly he needs (d). The final touch is to remind Kate of the relations they have (diminutive sis), love, and consolidate his role (e). It is the standard role of a younger brother that allows the speaker to manipulate such a decisive woman as Kate with ease.

The example (4) demonstrates the conversation of two manipulators; the standard roles (a mother and a son) are closely interwoven with the initiative roles (careful / benevolent). Each of them pursues their own hidden goals: Richard's mother wants to be as close as possible to her son, and her son, on the contrary, tries to distance himself from his mother. The manipulative action began with Sarah's idea of hiring her cook Mrs. Gleeson full time. This would allow her to invite her son to eat after work, and then she could always be a bit sick and Richard would be forced to stay (a). However, her caring son has his own plans. Mrs. Gleeson could take care of his mother, which would allow Richard to visit his mom less often. He asks about the possibility of such a scenario (b, c), as if being worried about Sarah. In fact, he simply makes tentative enquiries to be sure that the intended alternative is possible. But Sarah is an experienced manipulator, and therefore quickly realizes that she made a mistake. She changes the angle of attention, focusing on the disadvantages of the cook, noting that this is not such a great idea (d). At first Richard does not want to surrender (e), but a woman adds another communicative role to the range of strategies and tactics the weak and tired mom (f). 
(4) (a)'You could always come and have dinner with me in the evenings, when I get home. I could employ Mrs Gleeson full-time and she could cook dinner for us.' If she got him to come for dinner she could always say that she felt a little weak and he'd feel obliged to stay. (b)'Do you think Mrs Gleeson would take on the job fulltime? Doesn't she have family commitments? A deserted daughter or something?' Richard countered. (c)'It would be good if she could work longer hour, for you.' Richard stood up and began to pace up and down. Sarah suddenly realized that she had made a big mistake. If Hannah Gleeson came to work long hours, Richard would feel he was off the hook and probably visit less and less. (d) 'Maybe not, though,' she said hastily. 'I find her tedious sometimes. We'll see.' (e) 'But Mother-Sarah raised a hand.(f)'Not now, Richard. I'm tired. You may go.' She used her weaker-than-weak voice (Scanlan, 2000: 302-303).

It is known that we perform several roles simultaneously. As J. Coats notes, "All kinds of different "self" are possible, because our culture offers us a wide range of ways of being - but all these ways of being are gendered" (Coates, 1997: 285). However, in the case of verbal manipulation, one of the standard social roles is concealed by activating another.

(5) (a) 'We've both been through the mill a bit, haven't we? How's things with you?' 'Bad,' said Octavia briefly. 'I've told Tom I want a divorce. I think he's hoping still I'll come round. Forgive him. All that crap. '(b) 'No chance?' 'No chance.' (c) 'And Tom still hasn't told you who it is?' 'No. He's avoiding talking about the whole thing. I think it's partly because - oh, I shouldn't tell you. (...) (d) 'Boot, who am I going to tell? Living in this backwater.' 'You mustn't tell Sandy even. He might talk.' 'I won't tell Sandy, but-' (e)'Okay, then. I need to tell someone anyway. Fleming Cottrell are in trouble. I mean real trouble. They've got to get hold of some more money fast, or they could go bust.' (f) 'My God. Really?' 'Yes. Our house is remortgaged right up to the hilt, and so is Aubrey's. If the bank foreclosed, well... (g) 'But why so secret? I don't understand.' 'It's the pack-of-cards thing. If the clients he's got, even one of them, heard the company was dodgy, one of them might pull out too. Then he really would have had it.' (h)'Oh, dear. Yes, I see. (...)(i) 'You shouldn't feel bad about anything you do to Tom.'(...) (j) 'He can get hold of some money, it isn't difficult. They're drowning in money in the City, Daddy says. (k) Do you want me to ask him? Maybe he could help' (Vincenzi, AC, 2002: 222).

The initiator of the verbal manipulation (Louise) positions herself as the best friend, and therefore easily asks about problems with her friend's husband and, therefore, receives all the necessary information. The use of inclusive pronoun we in the very beginning of the dialogue (We've both been through the mill a bit, have not we?) helps Louise to reduce the communicative distance between her and the addressee. Specific features of female interaction also contribute to successful manipulation, i.e. affective words-intensifies which are used to express the emotional relationship more than denotative information ( $m y$ god, really, oh, dear), a tagquestion (s), kid's nickname Boot, which is used only by Louise to address Octavia. At the end of the dialogue, she reinforces her standard role offering her help (Do you want to ask him? Maybe he could help). It is important to emphasize that in the women's verbal consciousness emotionality is combined with their ability to selfdisclosure (Okay, then. I need to tell someone anyway). In the cognitive aspect, it is 
manifested in the reduction of the distance between the cognitive personality and the referent (Potapov, 2002: 122). But in fact, Louise hides another standard role Octavia's husband's mistress. All of the friend's questions are aimed not at explicitly expressed sympathy and support. But in fact, it's a kind of interrogation because the received information (b, c, f), will be later used against the man. In addition, the standard role of a friend allows her to give bits of advice which spoil the relations of the couple in the long run $(i, j)$.

To sum up, the factual material demonstrates that at the level of the addresser - addressee in the dialogical manipulative situation, interaction takes place between communicators who take on one or another communicative role and, as a rule, these roles are decisive. Within our study, female verbal manipulative behavior has standard roles: a mother (31\%), a girlfriend (19\%), a sister (12.5\%), and occasionally a spouse $(6.5 \%)$. It should be noted that among men the percentage of using standard roles with a manipulative goal is lower than in the opposite sex: a son $(12.5 \%)$, a husband $(12.5 \%)$, and a brother $(6 \%)$.

All of these communicative roles are referred to as a cooperative type of a manipulator, the main characteristic of which is, firstly, a destructive impulse that is directed at the addressee. Secondly, it is a hidden conflict of interest. This type is opposed to another, namely, a conflictive type of a manipulator. The preliminary point is that some types of manipulation have an open confrontational nature, where on the communicative level the addresser's intention are contrary to the addressee's intentions.

In this study we refer to K.F. Sedov's theory (Sedov, 2003: 303), which focuses on differentiation of linguistic personality according to his / her communicative capacity for cooperation. The scholar identifies a conflictive manipulative subtype of the conflictive type of linguistic personality's verbal behavior. This type of the manipulator concentrates on interaction, in the course of which one of the communicators (the manipulator) asserts himself / herself through demonstrating his superior attitude to the addressee. He does not feel respect for the addressee, considers him intellectually and / or ethically less educated. The dominant illocutionary purpose in verbal behavior of a linguistic personality is imposing opinions, exaggerating the importance of his / her own experience. In the course of interaction the manipulator shows himself / herself in giving instructions, advice, dictatorship, and, moreover, in the specific manner of communication (e.g., asking too many questions without listening the answers back, rough interruptions for the purpose of changing a topic). According to K.F. Sedov, there are conflict generators in the conflictive manipulator's behavior, whose purpose is to humiliate communication partner". On the basis of this theory, we assume that it is appropriate to differentiate active conflictive and passive conflict subtypes of manipulators.

Mrs. Yates in the fragment (6) belongs to the first subtype of the manipulator. The DMS is the following: the speaker A is the son who came to inform his mother about the divorce and his moving to another country. Speaker B (Mrs. Yates) is his mother who thinks she's a true Christian and a religious woman. From her point of view divorce is a sin and shame of the whole family, so she begins to use her personal means of influence that are always used to achieve the goal. Initially, she implements mother's authoritarian opinion, i.e. explicitly forbids him to do it (a), and then uses the manipulative tactics of threat (b). Then Mrs. Yates tries to excite pity (e), sense of 
duty implementing the tactic of accusation $(d, c)$. And as a result, the woman gains her point.

(6) A:'We're getting a divorce.' There! It was said. Out in the open.

B: (a) 'Divorced! Under no circumstances. I'll not permit it, Richard. Do you hear me? You will not disgrace the family name with a divorce.(b)I'll cut you out of the will again. You'll be excommunicated. I've never heard such ....such sacrilege.'(...)

A: 'Mother, for God's sake! (...) 'I'm saying it once more. I'm selling up and emigrating. And Caroline and I are divorcing.' He glared at his mother.

B: (c)'After all I did for you? I reared you single-handedly. I sent you to college. I gave you the money to set you up. (d) You're an ingrate, Richard. A selfish uncaring son, ready to drag our good name through the gutter. What will the relations think? What will the neighbours say? What will all your father's respected friends think? (e) And how will I manage when you've ... emigrated? I'm an elderly woman ... alone.' Sarah was incandescent (Scanlan, 2000: 55-56).

Consequently, the use of such communicative tactics as condemnation, accusation, threat, order is characteristic for an active-conflictive subtype of the manipulator. As to the gender identity of this subtype, in our actual speech material, men are in the majority (64\%), while only $36 \%$ of women belong to this subtype.

The second subtype of the manipulator is presented in the example (7).

(7) (a)'You'll never guess,' breathed Sheila, all flushed cheeks and bright eyes...(...) 'Hey Sheila,' said Shaun. Just say what's on your mind.' 'Hah!' exclaimed Sheila. 'You'd never recover old man.' Sheila turned to Jo and gave her a present. (b)'It's crap and you've probably got one. "Wow!' exclaimed Jo. 'You shouldn't have! Shall I open it now or-?'(c) 'So!' exclaimed Sheila. 'I swear! You'll never guess!' Jo put her present on the floor by her bag. 'What?' she asked (Nathan, N, 13-14).

Joe celebrates her birthday, and her friend Sheila is trying to attract attention by all means. At first, she is late for the party (such act already attracts attention). She starts communication with the indirect directive (a), the illocutionary message of which is: ask me what happened. Sheila does not give Joe the opportunity to even thank everyone for the gift $(b, c)$, reinforcing the interest with intensifying utterances (I swear, so).

The passive conflictive subtype of the manipulator prefers to use tactics of ignorance and interruption. The analysis of the illustrative material proves that both men and women rarely implement these tactics, especially in heterogeneous groups.

\section{Conclusion}

Dialogical manipulative situations have been revealed on the basis of their discursive, communicative pragmatic characteristics. K. Serazhym's communicative model is taken as the basis for the simulating of the dialogical manipulative situation structure. The central components of the dialogical manipulative situation are an addresser, an addressee, a message, an addresser's world, an addressee's world, an imaginative world of an addresser, an imaginative world of an addressee, a social situation (temporal and physical space of communication). 
Communicative roles are regarded as a basic constituent part of the "addresseraddressee" level of the dialogical manipulative situation. They are divided into standard and initiative. The latter is subdivided into active (which are experienced / reputable, caring / friendly, interested) and passive (inexperienced, weak / tired, a simpleton). Standard communicative roles (such as the role of a mother, a girlfriend, a brother, etc.) also contribute to effective verbal manipulation. Women's manipulative speech is characterized by initiative roles of care, benevolence and interest. For men, such a communicative behavior is possible on condition they are combined with the role of an expert or the standard communicative role. Women also use the role of an expert, but in combination with the standard roles of their sister, girlfriend, and mother.

The conflict type of the manipulator is regarded as the addresser whose goals on the communicative level are contrary to the addressee's intentions. Overall, the findings attest that the conflictive type of the manipulator is characterized by conflicts where confrontation occurs between different role-based positions of communicants, usually spouses, parents and children, a teacher and a student. A manipulator, who chooses this line of conduct, teaches, interrupts, orders, prohibits, ignores his / her recipient, since their standard role allows them to act this way.

\section{References}

Bykova, Olga. 1999. "Yazykovoie manipulirovaniie." Teoreticheskie i prikladnyie aspektyi rechevogo vozdeystviya: Vestn. Rossiyskoy ritoricheskoy assotsiatsii 1 (8). Krasnoyarsk. Accessed July 27, 2012. http://library.krasu.ru/ft/ft/_articles/ 0070503.pdf

Velychko, Elena. 2008. "Sposoby vyrazheniia kommunikativnoy initsiativy: gendernyi aspekt (na materiale sovremennogo angliyskogo yazyka)." PhD diss.. University of Rostovna-Donu.

Dementev, Valerij. 2006. Nepryamaya kommunikatsiya. Moscow: GNOZIS.

Dmytruk, Olga. 2006. "Manipuliatyvni stratehii v suchasnii anhlomovnii komunikatsii (na materiali tekstiv drukovanykh ta Internet-vydan 2000-2005 rr.)." PhD diss., Taras Shevchenko National University of Kyiv.

Kara-Murza, Sergey. 2009. Manipulyatsiya soznaniem. Moscow: EKSMO, Algoritm.

Karpchuk, Nataliia. 2006. Adresovanist v ofitsiinomu ta neofitsiinomu anhlomovnomu dyskursi. Lutsk: Vezha.

Mikhaleva, Olga. 2003. "Yazyikovyie sposoby manipulirovaniya soznaniem v politicheskom diskurse." Aktualnyie problemyi rusistiki 2, ch. 2: 225-232. Edited by T. Demeshkina. Tomsk: Izd-vo Tomskogo un-ta. Accessed April 23, 2018. http://www.prbaikal.com/ about/group/mikhaleva/.

Nikolaeva, Zhanna. 2004. Osnovyi teorii kommunikatsii. Ulan-Ude: VSGTU.

Potapov, Vsevolod. 2002. "Mnogourovnevaya strategiya v lingvisticheskoy genderologii." Voprosyi yazyikoznaniya 1: 103-130.

Sedov, Konstantin. 2003. "O manipulyatsii i aktualizatsii v rechevom vozdeystvii." Problemyi rechevoy kommunikatsii 2: 20-27. Edited by M. Kormilitsinoy. Saratov: Izd-vo Saratov. un-ta.

Serazhym, Kateryna. 2002. Dyskurs yak sotsiolinhvalne yavyshche: metodolohiia, arkhitektonika, variatyvnist. Kyiv : Kyiv. nats. un-t imeni T. H. Shevchenka.

Stepanov, Yurii. 1995. "Alternativnyi mir, diskurs, fakt i printsip prichinnosti." Yazyik i nauka kontsa 20 vek : 35-73. Moscow : Ros. gos. gum. un-t. 
Sternin, Iosif. 2001. Vvedenie v rechevoe vozdeystvie. Voronezh: Izd-vo VGU.

Susov, Ivan. 1986. "Pragmaticheskaya struktura vyiskazyivaniya." Yazyikovoe obschenie i ego edinitsyi : 7-11. Kalinin: KGU.

Formanovskaya, Nataliya. 2002. Rechevoe obshchenie: kommunikativnopragmaticheskiy podhod. Moscow: Rus. yaz..

Hymes, Dell. 1975. "Etnografiya rechi." Novoe v zarubezhnoy lingvistike 7: 42-94. Moscow: Progress.

Chaly, Victor. 2008. "Problemyi issledovaniya rechevoy manipulyatsii v hudozhestvennoy proze." Vestnik Nizhegorodskogo un-ta im. N. I. Lobachevskogo. Seriya : Filologiya. Iskusstvovedenie 6: 234-239. Nizh. Novgorod: Izd-vo Nizhegorodskogo un-ta im. N. I. Lobachevkogo.

Shmidt, Z. 1978. "Tekst" i "istoriya" kak bazovyie kategorii." Novoe v zarubezhnoy lingvistike 8: 89-108. Moscow: Progress.

Yacobson, Roman. 1975. Lingvistika i poetika Strukturalizm "za” $i$ "protiv". Edited by M. Gasparova, 193-288. Moscow: Progress.

Coates, Jennifer. 1997. "Competing Discourses of femininity.” Communicating Gender in Context, edited by H. Kotthoff, R. Wodak, 285-314. Amsterdam, Philadelphia: John Benjamins Publishing Company.

Holmes, Janet, and Meyerhoff, Miriam, edit.2003. The Handbook of Language and Gender. Oxford: Blackwell Publishing Ltd.

Tannen, Deborah. 1990. You Just Don't Understand: Women and Men in Conversation. NY: Morrow.

Vespa, Jonathan. 2009. "Gender Ideology Construction: A Life Course and Intersectional Approach" Gender \& Society 23: 363 -388.

Scanlan, Patricia. 2000. City Lives. London: Bantam Books.

Sheldon, Sidney. 2005. Master of the Game (MG). London: HarperCollins Publishers.

—. 1995. Nothing Lasts Forever (NLF). London: Harper Collins Publishers.

Vincenzi, Penny. 2007. Almost a Crime (AC). London: Orion.

—. 2004. No Agel (NA). London: Orion. 